\title{
THE ROLE OF HONEY IN PEDIATRIC TREATMENTS IN SRI LANKAN SIDDHA MEDICINE
}

\author{
Sri Lanka Siddha Medicine'de Pediatrik Tedavilerde Balın Rolü
}

\section{Pholtan Rajeev Sebastian RAJAMANOHARAN ${ }^{1,2}$, Saravanan VIVEKANANDARAJAH SATHASIVAMPILLA $\left.\right|^{3,4^{*}}$}

\author{
${ }^{1}$ Eastern Provincial Herbal Garden Management Center, Trincomalee, Sri Lanka \\ ${ }^{2}$ Department of Siddha Toxicology, The Tamil Nadu Dr. M.G.R. Medical University, Chennai, INDIA, ORCID No: 0000- \\ 0001-9341-5843, Email address: drsrprajeev@gmail.com \\ ${ }^{3}$ KnowledgeLink Group, Inc., Waltham, MA 02451, USA. \\ $4^{*}$ Boigai Institute, Batticaloa, SRI LANKA, ORCID No: 0000-0002-5938-0509, Corresponding Author: e-mail: \\ vivekanandarajahs@yahoo.co.uk
}

Geliş Tarihi / Received: 31.12.2020

Kabul Tarihi / Accepted:05.02.2021

DOI: $10.31467 /$ uluaricilik.851567

\begin{abstract}
Honey is used as food and for the treatment of indigenous medicines worldwide, also in Sri Lanka for a long time. Siddha Medicine is one of the four indigenous medicines currently practiced in Sri Lanka and is generally practiced in the Eastern and Northern Provinces of Sri Lanka. This study aims to explore and highlight the use of honey in pediatric treatments in Sri Lankan Siddha Medicine. Preparations used to treat pediatric disorders were obtained from standard Sri Lankan textbooks used in Siddha Medicine degree programs at universities in Sri Lanka [Pararasaseharam (Part Two) and Seharasasehara Treatment]. A total of $\mathbf{3 0}$ preparations were identified using honey as an ingredient or adjuvant. Honey is generally used to treat indigestion and disorders associated with the digestive system. This is the first study on the role of honey in pediatric treatments in Sri Lankan Siddha Medicine. This work identified, analyzed, and documented the use of honey in pediatric treatments in Sri Lankan Siddha Medicine.
\end{abstract}

Keywords: Sri Lanka, Siddha Medicine, honey, pediatric treatments

Öz

Bal, gıda olarak ve dünya çapında yerli ilaçların tedavisinde ve ayrıca Sri Lanka'da uzun süredir kullanılmaktadır. Siddha Medicine şu anda Sri Lanka'da uygulanmakta olan dört yerli ilaçtan biridir ve genellikle Sri Lanka'nın Doğu ve Kuzey İllerinde uygulanmaktadır. Bu çalışma, Sri Lanka Siddha Medicine'de pediatrik tedavilerde balın kullanımını araştırmayı ve vurgulamayı amaçlamaktadır. Pediyatrik bozuklukları tedavi etmek için kullanılan hazırlıklar, Sri Lanka'daki [Pararasaseharam (İkinci Kısım) ve Seharasasehara Tedavisi] üniversitelerindeki Siddha Tıp derecesi programlarında kullanılan standart Sri Lanka ders kitaplarından elde edildi. Bir bileşen veya yardımcı madde olarak bal kullanılarak toplam 30 preparat tanımlandı. Bal genellikle hazımsızlık ve sindirim sistemi ile ilgili rahatsızlıkları tedavi etmek için kullanılır. Bu, Sri Lanka Siddha Medicine'de balın pediatrik tedavilerdeki rolü üzerine yapılan ilk çalışmadır. Bu çalışmada, Sri Lanka Siddha Medicine'de pediatrik tedavilerde balın kullanımını belirlendi, analiz edildi ve belgelendi.

Anahtar Kelimeler: Sri Lanka, Siddha Medicine, bal, pediatrik tedaviler 


\section{GENIŞLETILMIŞ ÖZET}

Amaçlar ve Hedefler: Bu çalışma, Sri Lanka Siddha Medicine'de pediatrik tedavilerde balın kullanımını araştırmayı ve vurgulamayı amaçlamaktadır. Ayrıca, bu sistematik inceleme, Sri Lanka balıyla ilgili gelecekteki farmakolojik araştırmalar için faydalı olacaktır.

Balın tedavideki rolü: Sri Lankan Siddha Medicine pediatrik tedavilerinde balın müstahzar adı, tedavisi, ilacın türü, yardımcı ve referansı dahil bilgiler Tablo 1 'de listelenmiştir. Çeşitli pediatrik bozukluklar için toplam 72 preparat iki kaynakta da listelenmiştir: (Ponniahpilai 2016, Ponniahpilai 2000). Ancak bal, 72 preparatın 30'unda bir bileşen veya yardımcı madde olarak kullanılmaktadır. Ayrıca, bal belirli bir preparatta bir bileşen olarak kullanılırsa, bu preparasyonda bir adjuvan olarak kullanılmaz ve bunun tersi de geçerlidir. Dolayısıyla bu, müstahzarlarda kullanılan diğer maddelerle karşılaştıııldığında, balın temel olarak pediatrik tedavilerde kullanılan tek madde olduğunu göstermektedir. Bu nedenle, bu bilgiler balın Sri Lanka Siddha Medicine'de pediatrik tedavilerde yer alan en önemli madde olduğunu ortaya koymaktadır. Tedavilerin çoğu (16 preparat ve adjuvan) Ponniahpillai'de (2016), ardından Ponniahpillai'de (2000) tanımlanmıştır.

Ayrıca bal, çoğunlukla pediyatrik tedavilerde yardımcı madde olarak kullanılmaktadır. Öncelikle toz preparatlarla bir adjuvan olarak ve ardından haplar olarak kullanılır. Buna ek olarak, bal genellikle tonik ve kaynatmada bir bileşen olarak kullanılır, ardından pediatrik tedavilerde haplar ve tozlar gelir. Bal genellikle pediatrik bozukluklarda hazımsızlık, ishal, kızarıklık, ateş ve öksürügü tedavi etmek için kullanılır. İnsan vücudu sistemleri açısından, genellikle sindirim, solunum, deri, iskelet, kas, sinir ve kardiyovasküler sistemlerle ilişkili bozuklukları tedavi etmek için kullanılır. Yukarıda bahsedildiği gibi, balın anti-enflamatuar, antibakteriyel, yara iyileştirme ve antifungal aktivite çalışmaları, eklem hastalığı, kızarıklık ve öksürük dahil olmak üzere Sri Lanka Siddha Tıbbında pediatrik tedavilerde kullanımına dair bilimsel kanıt sağlar. Modern tıpta pediatrik tedavide balın kullanıldığı birçok klinik araştırma mevcuttur. Bu çalışmalar, balın Siddha tıbbı da dahil olmak üzere geleneksel ilaçlar üzerindeki iyileştirici etkilerinin bilimsel kanıtlarını sağlar. Örneğin, pediyatrik klinik çalışmalar öksürük, yaralar, solunum yolu enfeksiyonları, bacaklarda kronik venöz ülserler, iltihaplı, hasarlı cilt, herpes, gastroenterit, yetersiz beslenme, yanıklar, mukozit, dehidratasyon ve diş çekimi yaralarının iyileştirici etkilerini göstermiştir (Abdel-Naby Awad ve Hamad, 2018, Abdulrhman v.d. 2011, Abdulrhman v.d. 2010, Aly v.d. 2017, Haffejee ve Moosa, 1985, Konuk Sener ve diğerleri 2019, Mokhtari v.d. 2019, Paul, 2012, Shaaban v.d. 2010, Shadkam v.d. 2010, Simon v.d. 2006).

Sonuç: Bu, Sri Lanka Siddha Medicine'de balın pediatrik tedavilerdeki rolü üzerine yapılan ilk çalışmadır. Bal, Sri Lanka Siddha Medicine'de pediatrik tedavilerde hayati bir rol oynar. Ancak bu preparatlarla bilimsel kanıt sağlamak için herhangi bir çalışma yapılmamıştır. Bu nedenle, bilimsel kanıtların yanı sıra güvenlik ve etkililik amaçları sağlamak için daha fazla in vitro, in vivo ve klinik deneyler yapılmalıdır. Bu çalışmada, Sri Lanka Siddha Medicine'de pediatrik tedavilerde balın kullanımını belirlendi, analiz edildi ve belgelendi. Ek olarak, bu çalışma, Sri Lanka Siddha Tıbbında pediatrik tedavilerde bal içeren preparatlar ve yardımcıların daha ileri farmakolojik çalışmaları için temel sağlar.

\section{INTRODUCTION}

In Sri Lanka, 132 bee species belonging to four families (Apidae, Megachilidae, Halictidae, and Colletidae) were documented (Wijesekara 2001). Sri Lanka hosts three species of bees: Apis dorsata Fabricius (sourced in the district of Matale), Apis florea Fabricius (sourced in the districts of Kandy, Puttalam, Matale, Matara, and Trincomalee), and Apis cerana Fabricius (sourced in the districts of Badulla and Galle) (Punchihewa 1994, Wijesekara 2001). Honey is used as food and medicine in indigenous medicines globally also, in Sri Lanka for a long time. The taste of honey varies depending on the types of flowers from which nectar is collected. Plants of families such as Asteraceae, Fabaceae (Mimosa pudica L.; Vachellia leucophloea (Roxb.) Maslin, Seigler \& Ebinger; Tephrosia purpurea (L.) Pers.; Gliricidia sepium (Jacq.) Steud.; Acacia auriculiformis A.Cunn. ex Benth.; and Cassia fistula L.), Asteraceae (Tithonia diversifolia (Hemsl.) A.Gray; Wollastonia biflora (L.) DC.; and Sphagneticola trilobata (L.) Pruski), Myrtaceae (Eucalyptus camaldulensis Dehnh.), Acanthaceae (Strobilanthes lupulina Nees), Malvaceae, and 
Poaceae are the primary sources of pollen and nectar for honeybees in Sri Lanka (Silva et al., 2018).

Honey consists mainly of water and sugars such as fructose, glucose, and sucrose. It also contains folate, niacin, pantothenic acid, riboflavin, vitamin $\mathrm{C}$, pyridoxine, proteins, minerals, pinocembrin, hesperetin, quercetin, chrysin, apigenin, galangin, kaempferol, ellagic acid, ferulic acid, p-coumaric acid, and caffeic acid (Allsop and Miller 1996, EterafOskouei and Najafi 2013, Zumla and Lulat 1989). Scientific studies have revealed that honey includes anti-inflammatory, antioxidant, wound healing, antidiabetic, antibacterial, and antifungal activities (Aljadi and Kamaruddin 2004, Al-Mamary et al. 2002, Al-Waili 2005, 2004, 2003, Al-Waili and Boni 2003, Asadi-Pooya et al. 2003, Bansal et al. 2005, Beretta et al. 2005, Bilsel et al. 2002, Blasa et al. 2006, Brady et al. 1996, Chepulis 2007, Chua et al. 2013, Efem 1988, Frankel et al. 1998, Gheldof and Engeseth 2002, Jeffrey and Echazarreta 1996, Meda et al. 2004, Molan 1999, Obaseiki-Ebor and Afonya 1984, Olaitan et al. 2007, Schramm et al. 2003, Shimazawa et al. 2005, Yaghoobi et al. 2008).

Siddha Medicine is one of the four indigenous medicines currently practiced in Sri Lanka and is commonly practiced in the Eastern and Northern Provinces of Sri Lanka (Weragoda 1980). Siddha Medicine originated in South India in the time from 10,000 to 4,000 B.C. (Siddha National Institute, 2016). A total of 4,448 diseases have been listed in Siddha Medicine (Government of Kerala, 2011). The treatments offered in Siddha Medicine are individual and are based on age, sex, physical state, diet, lifestyle, environment, habitat, habits, patient, physiological structure, weather, mental state, and appetite (Ministry of Ayurveda, Yoga, and Naturopathy, Unani, Siddha, and Homoeopathy, 2017). The raw materials used for Siddha medicinal preparations come from plants, animals, metals, minerals, and marine organisms. In addition to these types of raw materials, honey is also widely used in a variety of preparations in Siddha Medicine (Siddha National Institute, 2016). Seven types of honey are used in Siddha medicinal preparations, including hill honey, tree branch honey, tree hole honey, anthill honey, domestic honey, fresh honey, and old honey (Parasuraman and Perumal, 2020).

This study aims to explore and highlight the use of honey in pediatric treatments in Sri Lankan Siddha Medicine. Furthermore, this systematic review would be useful for future pharmacological research on Sri Lankan honey.

Preparations used for the treatment of pediatric disorders obtained from the Sri Lankan standard university textbooks used in Siddha Medicine degree programs in Sri Lanka: Pararasaseharam (Part Two) [Pararaasasharam (Irendaam Paaham)] (Ponniahpilai 2016) and Seharaasashahara Treatment [Seharaasashahara Vaithththiyam] (Ponniahpilai 2000). Only preparations involving honey as an ingredient or adjuvant taken into account in this study.

\section{The role of honey in treatments}

The information, including the name of the preparation, treatment for, type of medication, preparation/adjuvant, and reference of the use of honey in Sri Lankan Siddha Medicine pediatric treatments are listed in Table 1. A total of 72 preparations for various pediatric disorders are listed in both sources: Ponniahpilai (2016) and Ponniahpilai (2000). However, honey is used as an ingredient or adjuvant in 30 of the 72 preparations. Also, if honey is used as an ingredient in a particular preparation, then it is not used as an adjuvant with that preparation, and vice versa. Hence, this shows that honey is the only substance mainly used in pediatric treatments, compared to other substances used in the preparations. Therefore, this information reveals that honey is the most important substance involved in pediatric treatments in Sri Lankan Siddha Medicine. Most of the treatments (16 preparations and adjuvants) were identified in Ponniahpillai (2016), followed by Ponniahpillai (2000). 
Table 1: Use of honey in pediatric treatments

Tablo 1: Pediatrik tedavilerde bal kullanımı

\begin{tabular}{|c|c|c|c|c|}
\hline Name of preparation & Treatment for & $\begin{array}{l}\text { Type of } \\
\text { medication }\end{array}$ & $\begin{array}{l}\text { Preparation / } \\
\text { adjuvant }\end{array}$ & Reference \\
\hline Akkarahaara Sanjeevi Maaththirai & Fever & Pill & Adjuvant & $\mathrm{P}$ \\
\hline Akkarahaara Kulihai & Diarrhea, fever, coma & Pill & Adjuvant & $\mathrm{P}$ \\
\hline Athisaara Piththath Thool & Dysentery & Powder & Adjuvant & $\mathrm{S}$ \\
\hline Iraththa Piththam & Blood disorders & Powder & Adjuvant & $\mathrm{S}$ \\
\hline Uraththa Piththa Vaathath Thool & Indigestion, joint disorders & Powder & Adjuvant & $\mathrm{S}$ \\
\hline Elaathi Maaththirai & Fever, indigestion & Pill & Adjuvant & $\mathrm{P}$ \\
\hline Ongaalaththuk Kasaayam & Nausea, vomiting & Decoction & Preparation & $\mathrm{P}$ \\
\hline Karappaan Patrpam & Skin rashes & Powder & Adjuvant & $\mathrm{S}$ \\
\hline Karappaan Piththath Thool & Skin lesion & Powder & Adjuvant & $\mathrm{S}$ \\
\hline $\begin{array}{l}\text { Kasththoorimiruththiyaathi } \\
\text { Maaththirai }\end{array}$ & Cough & Pill & Adjuvant & $\mathrm{P}$ \\
\hline Kiranthi Vaathath Thool & Joint diseases, skin rashes & Powder & Adjuvant & $\mathrm{S}$ \\
\hline Kumaran Velkanda Ilehiyam & Cough, vomit & Tonic & Preparation & $\mathrm{S}$ \\
\hline Koolppaada Ilehiyam & Cough & Tonic & Preparation & $\mathrm{S}$ \\
\hline Sayapiththath Thool & Tuberculosis, indigestion & Powder & Adjuvant & $\mathrm{S}$ \\
\hline Sittramattik Kulihai & Indigestion & Pill & Adjuvant & $\mathrm{P}$ \\
\hline Suravikkatrool & Fever, hiccough & Powder & Adjuvant & $\mathrm{S}$ \\
\hline Suwarkkakkorosanai Maaththirai & Fever, indigestion, diarrhea & Pill & Adjuvant & $\mathrm{P}$ \\
\hline Suwasa Piththath Thool & Respiratory disorders & Powder & Adjuvant & $\mathrm{S}$ \\
\hline Suwasaththitrku Enaathik Kulihai & Asthma & Pill & Preparation & $\mathrm{S}$ \\
\hline Neermaanthath Thool & Indigestion & Powder & Preparation & $\mathrm{P}$ \\
\hline $\begin{array}{l}\text { Paravaichchsuraththitrkuk } \\
\text { Kasaayam }\end{array}$ & Fever & Decoction & Preparation & $P$ \\
\hline Perungaayak kulihai 1 & Indigestion, diarrhea, fever, cough & Pill & Adjuvant & $\mathrm{P}$ \\
\hline Perungaayak kulihai 2 & Indigestion, diarrhea & Pill & Adjuvant & $P$ \\
\hline Paanthasannikkuk kulihai & Indigestion, coma & Pill & Adjuvant & $\mathrm{P}$ \\
\hline Miruththiyaathik Kulihai & Indigestion, fever & Pill & Adjuvant & $P$ \\
\hline Vaathapatrpath Thool & Joint diseases & Powder & Adjuvant & $\mathrm{S}$ \\
\hline Vaayvu Vikkatrool & Hiccough & Powder & Adjuvant & $\mathrm{S}$ \\
\hline Vikkat Silettumath Thool & Hiccough & Powder & Adjuvant & $\mathrm{S}$ \\
\hline Virana Piththath Thool & Wounds & Powder & Adjuvant & $\mathrm{S}$ \\
\hline Venkaayak Kulihai & $\begin{array}{l}\text { Abdominal distension, indigestion, } \\
\text { diarrhea }\end{array}$ & Pill & Adjuvant & $\mathrm{P}$ \\
\hline
\end{tabular}

Abbreviations: P: (Ponniahpillai, 2016); S: (Ponniahpillai, 2000)

Kısaltmalar: P: (Ponniahpillai, 2016); S: (Ponniahpillai, 2000) 
In addition, honey is mainly used as an adjuvant in pediatric treatments. It is used primarily as an adjuvant with powdered preparations followed by pills. In addition, honey is often used as an ingredient in tonic and decoction, followed by pills and powders in pediatric treatments. Honey is usually used to treat indigestion, diarrheic, rash, fever, and cough in pediatric disorders. In terms of human body systems, it is generally used to treat digestive, respiratory, integumentary, skeletal, muscular, nervous, and cardiovascular systems-associated disorders. As mentioned above, anti-inflammatory, antibacterial, wound healing, and antifungal activity studies of honey provide scientific evidence of its use in pediatric treatments in Sri Lankan Siddha Medicine, including joint disease, rash, and cough. There are several clinical trials available using honey in pediatric treatment in modern medicine. These studies provide scientific evidence of the healing effects of honey on traditional medicines, including Siddha medicine. For example, pediatric clinical studies have shown healing effects of cough, wounds, respiratory infections, chronic venous ulcers of the legs, inflammatory, damaged skin, herpes, gastroenteritis, malnutrition, burns, mucositis, dehydration, and tooth extraction wounds (Abdel-Naby Awad and Hamad, 2018, Abdulrhman et al. 2011, 2010, Aly et al. 201, Haffejee and Moosa, 1985, Konuk Sener et al. 2019, Mokhtari et al. 2019, Paul, 2012, Shaaban et al. 2010, Shadkam et al., 2010, 2010, Simon et al. 2006).

This is the first study on the role of honey in pediatric treatments in Sri Lankan Siddha Medicine. Honey plays a vital role in pediatric treatments in Sri Lankan Siddha Medicine. However, no study has been conducted to provide scientific evidence with these preparations. Therefore, further in vitro, in vivo, and clinical trials should be conducted to provide scientific evidence as well as safety and efficacy purposes. This work identified, analyzed, and documented the use of honey in pediatric treatments in Sri Lankan Siddha Medicine. In addition, this work provides the basis for further pharmacological studies of preparations and adjuvants that involve honey in pediatric treatments in Sri Lankan Siddha Medicine.

\section{Source of Finance}

This work received no funding.

\section{Contributions of all Authors}

Both authors contributed equally.

\section{Conflict of Interest}

The authors declared that there is no conflict of interest in this study.

\section{Acknowledgement}

The authors are thankful to their family members for their vital support to complete this work.

\section{REFERENCES}

Abdel-Naby Awad OG., Hamad AH. 2018. Honey can help in herpes simplex gingivostomatitis in children: Prospective randomized doubleblind placebo controlled clinical trial. Am J Otolaryngol. 39:759-763.

Abdulrhman, MA, Mekawy, MA, Awadalla, MM, Mohamed, AH. 2010. Bee honey added to the oral rehydration solution in treatment of gastroenteritis in infants and children. $\mathrm{J}$ Med Food. 13: 605-609.

Abdulrhman, MA., Nassar, MF., Mostafa, HW., ElKhayat, ZA., Abu El Naga, MW. 2011. Effect of honey on $50 \%$ complement hemolytic activity in infants with protein energy malnutrition: a randomized controlled pilot study. J Med Food. 14: 551-555.

Aljadi, AM., Kamaruddin, MY. 2004. Evaluation of the phenolic contents and antioxidant capacities of two Malaysian floral honeys. Food Chem. 85: 513-518, https://doi.org/10.1016/S03088146(02)00596-4.

Allsop, KA., Miller, JB. 1996. Honey revisited: a reappraisal of honey in pre-industrial diets. $\mathrm{Br}$. J. Nutr. 75: 513-520, https://doi.org/10.1079/bjn19960155.

Al-Mamary, M., Al-Meeri, A., Al-Habori, M. 2002. Antioxidant activities and total phenolics of different types of honey. Nutr. Res. 22: 10411047, https://doi.org/10.1016/S02715317(02)00406-2.

Al-Waili, NS. 2003. Effects of daily consumption of honey solution on hematological indices and 
blood levels of minerals and enzymes in normal individuals. J. Med. Food 6: 135-140, https://doi.org/10.1089/10966200332223354 9.

Al-Waili, NS. 2004. Investigating the antimicrobial activity of natural honey and its effects on the pathogenic bacterial infections of surgical wounds and conjunctiva. J. Med. Food. 7: 210-222,

https://doi.org/10.1089/1096620041224139.

Al-Waili, NS., Boni, NS. 2003. Natural honey lowers plasma prostaglandin concentrations in normal individuals. J. Med. Food 6: 129-133, https://doi.org/10.1089/10966200332223353 0.

Aly H., Said RN., Wali IE. 2017. Medically graded honey supplementation formula to preterm infants as a prebiotic: A randomized controlled trial. J Pediatr Gastroenterol Nutr. 64 :966970.

Asadi-Pooya, AA., Pnjehshahin, MR., Beheshti, S. 2003. The antimycobacterial effect of honey: an in vitro study. Riv. Biol. 96: 491-495.

Bansal, V., Medhi, B., Pandhi, P., 2005. Honey - a remedy rediscovered and its therapeutic utility. Kathmandu Univ. Med. J. (KUMJ) 3: 305-309.

Beretta, G., Granata, P., Ferrero, M., Orioli, M., Maffei Facino, R., 2005. Standardization of antioxidant properties of honey by a combination of spectrophotometric/fluorimetric assays and chemometrics. Analytica Chimica Acta 533: 185-191, https://doi.org/10.1016/j.aca.2004.11.010.

Bilsel, Y., Bugra, D., Yamaner, S., Bulut, T., Cevikbas, U., Turkoglu, U., 2002. Could honey have a place in colitis therapy? Effects of honey, prednisolone, and disulfiram on inflammation, nitric oxide, and free radical formation. Dig. Surg. 19: 306-311, https://doi.org/10.1159/000064580.

Blasa, M., Candiracci, M., Accorsi, A., Piacentini, MP., Albertini, MC., Piatti, E., 2006. Raw Millefiori honey is packed full of antioxidants. Food Chem. 97: 217-222, https://doi.org/10.1016/j.foodchem.2005.03.0 39.

\section{DERLEME / REVIEW}

Brady, NF., Molan, PC., Harfoot, CG. 1996. The Sensitivity of Dermatophytes to the Antimicrobial Activity of Manuka Honey and Other Honey. Pharm. Pharmacol. Commun. 2: 471-473, https://doi.org/10.1111/j.20427158.1996.tb00540.x.

Chepulis, LM., 2007. The effect of honey compared to sucrose, mixed sugars, and a sugar-free diet on weight gain in young rats. J. Food Sci. 72: S224-229, https://doi.org/10.1111/j.17503841.2007.00286.x.

Chua, LS., Rahaman, NLA., Adnan, NA., Eddie Tan, TT. 2013. Antioxidant activity of three honey samples in relation with their biochemical components. J. Anal. Methods Chem. 2013: 8, https://doi.org/10.1155/2013/313798.

Efem, SE. 1988. Clinical observations on the wound healing properties of honey. Br. J. Surg. 75: 679-681, https://doi.org/10.1002/bjs.1800750718.

Eteraf-Oskouei, T., Najafi, M. 2013. Traditional and Modern Uses of Natural Honey in Human Diseases: A Review. Iran J. Basic Med. Sci. 16: 731-742.

Frankel, S., Robinson, GE., Berenbaum, MR. 1998. Antioxidant capacity and correlated characteristics of 14 unifloral honeys. J. Apic. Res. 37: 27-31, https://doi.org/10.1080/00218839.1998.1110 0951.

Gheldof, N., Engeseth, NJ. 2002. Antioxidant capacity of honeys from various floral sources based on the determination of oxygen radical absorbance capacity and inhibition of in vitro lipoprotein oxidation in human serum samples. J. Agric. Food Chem. 50: 30503055, https://doi.org/10.1021/jf0114637.

Government of Kerala. 2011. About Siddha [WWW Document].

URL http://www.ism.kerala.gov.in/index.php/about -sidha.html (accessed 12.26.20).

Haffejee, IE., Moosa, A. 1985. Honey in the treatment of infantile gastroenteritis. Br Med J (Clin Res Ed). 290 :1866-1867.

Jeffrey, A., Echazarreta, C. 1996. Medical uses of honey. Rev. Biomed. 7.

Konuk Sener D., Aydin M., Cangur S., Guven E. 2019. The effect of oral care with chlorhexidine, vitamin $\mathrm{E}$ and honey on 


\section{DERLEME / REVIEW}

mucositis in pediatric intensive care patients: A randomized controlled trial. J Pediatr Nurs. 45: e95-e101.

Meda, A., Lamien, CE., Millogo, J., Romito, M., Nacoulma, OG. 2004. Therapeutic uses of honey and honeybee larvae in central Burkina Faso. J. Ethnopharmacol. 95: 103-107, https://doi.org/10.1016/j.jep.2004.06.016.

Ministry of Ayurveda, Yoga and Naturopathy, Unani, Siddha, and Homoeopath. 2017. Diagnosis and Treatment [WWW Document]. URL https://main.ayush.gov.in/about-thesystems/siddha/diagnosis-and-treatment (accessed 12.26.20).

Mokhtari S., Sanati I., Abdolahy S., Hosseini Z. 2019. Evaluation of the effect of honey on the healing of tooth extraction wounds in 4- to 9year-old children. Niger J Clin Pract. 22:13281334.

Molan, PC. 1999. Why honey is effective as a medicine. Bee World. 80: 80-92, https://doi.org/10.1080/0005772X.1999.1109 9430

National Institute of Siddha. 2016. About Siddha Medicine [WWW Document]. URL https://nischennai.org/siddhamedicine.html (accessed 12.26.20).

Obaseiki-Ebor, EE., Afonya, TC. 1984. In vitro evaluation of the anticandidiasis activity of honey distillate $(\mathrm{HY}-1)$ compared with that of some antimycotic agents. J. Pharm. Pharmacol. 36: 283-284, https://doi.org/10.1111/j.2042-

7158.1984.tb04373.x.

Olaitan, PB., Adeleke, OE., Ola, IO, 2007. Honey: a reservoir for microorganisms and an inhibitory agent for microbes. Afr. Health Sci. 7: 159165 , https://doi.org/10.5555/afhs.2007.7.3.159.

Parasuraman, S., Perumal, P. 2020. Siddha, an Indigenous Medical System of Peninsular India. Springer, Singapore.

Paul IM., Beiler J., McMonagle A. 2007. Effect of honey, dextromethorphan, and no treatment on nocturnal cough and sleep quality for coughing children and their parents. Arch Pediatr Adolesc Med. 161: 1140-6.

Paul, IM. 2012. Therapeutic options for acute cough due to upper respiratory infections in children. Lung. 190: 41-44.
Ponniahpillai, I., 2016. Pararasaseharam (Second Part)-பரராசசேகரம் (இரண்டாம் பாகம்)

[Pararaasaseharam (Irendaam Paaham)]. Provincial Department of Indigenous Medicine, Northern Province, Jaffna.

Ponniahpillai, I., 2000. Seharaasasehara Treatment-(Seharaasasehara Vaiththiyam)செகராசசேகர வைத்தியம். Provincial Department of Indigenous Medicine, Northern Province, Jaffna.

Punchihewa, RWK., 1994. Beekeeping for honey production in Sri Lanka. Sri Lanka Department of Agriculture, Peradeniya.

Schramm, DD., Karim, M., Schrader, HR., Holt, RR., Cardetti, M., Keen, CL. 2003. Honey with high levels of antioxidants can provide protection to healthy human subjects. J. Agric. Food Chem. 51: https://doi.org/10.1021/jf025928k.

Shaaban, SY., Abdulrhman, MA., Nassar, MF., Fathy, RA. 2010. Effect of honey on gastric emptying of infants with protein energy malnutrition. Eur J Clin Invest. 40 :383-387.

Shadkam MN., Mozaffari-Khosravi H., Mozayan MR. 2010. A comparison of the effect of honey, dextromethorphan, and diphenhydramine on nightly cough and sleep quality in children and their parents. J Altern Complement Med. 16: 787-93.

Shimazawa, M., Chikamatsu, S., Morimoto, N., Mishima, S., Nagai, H., Hara, H. 2005. Neuroprotection by Brazilian Green Propolis against In vitro and In vivo Ischemic Neuronal Damage. Evid. Based. Complement. Alternat. Med. 2: 201-207, https://doi.org/10.1093/ecam/neh078.

Silva, H., Seneviratne, R., Gunawardana, M., Jayasinghe, C. 2018. Pollen Analysis of Natural Bee Honeys from Different Regions of Sri Lanka. J. Food Agric. 11: 23, https://doi.org/10.4038/jfa.v11i1.5200.

Simon A., Sofka K., Wiszniewsky G. 2006. Wound care with antibacterial honey (Medihoney) in pediatric hematology-oncology. Support Care Cancer. 14: 91-7.

Weragoda, PB. 1980. The traditional system of medicine in Sri Lanka. J. Ethnopharmacol. 2: 71-73, https://doi.org/10.1016/03788741(80)90033-1. 
Wijesekara, A. 2001. An Annotated List of Bees (Hymenoptera: Apoidea: Apiformis) of Sri Lanka. Tijdschr. Entomol. 144: 145-158, https://doi.org/10.1163/22119434-99900063.

Yaghoobi, N., Al-Waili, N., Ghayour-Mobarhan, M., Parizadeh, SMR., Abasalti, Z., Yaghoobi, Z., Yaghoobi, F., Esmaeili, H., Kazemi-Bajestani, SMR., Aghasizadeh, R., Saloom, KY., Ferns,

\section{DERLEME / REVIEW}

GA. 2008. Natural honey and cardiovascular risk factors; effects on blood glucose, cholesterol, triacylglycerole, CRP, and body weight compared with sucrose. Sci. World J. 8: 463-469, https://doi.org/10.1100/tsw.2008.64.

Zumla, A., Lulat, A. 1989. Honey - a remedy rediscovered. J. R. Soc. Med. 82: 384-385. 